Article

\title{
Eco-Innovative Museums and Visitors' Perceptions of Corporate Social Responsibility
}

\author{
Namho Chung ${ }^{1} \mathbb{D}$, Inessa Tyan ${ }^{2}$ and Seung Jae Lee ${ }^{1, *}$ \\ 1 College of Hotel \& Tourism Management, Kyung Hee University, 26 Kyungheedae-ro, Dongdaemun-gu, \\ Seoul 02447, Korea; nhchung@khu.ac.kr \\ 2 Faculty of Tourism, University of Malaga, Leon Tolstoi str., 29071 Malaga, Spain; inessa-jang@hotmail.com \\ * Correspondence: sjleeth@khu.ac.kr
}

Received: 23 August 2019; Accepted: 14 October 2019; Published: 17 October 2019

check for updates

\begin{abstract}
This study assumes that green technologies at tourist destinations are a part of corporate social responsibility (CSR). It investigates how technology-based eco-innovation is related to sustainable development goals (SDGs) and how eco-innovative CSR performance affects tourists' perceptions of destinations, emotions, and WOM (word of mouth) intentions in the context of sustainability and smart tourism. A dataset collected from the Handok Museum in South Korea was analyzed via a partial least squares (PLS) method, using structural equation modeling. This study examines the link between museum visitors' awareness of CSR and green technology. The constructs (perceived quality, image, and reputation) are positively correlated with CSR; museum visitors' emotions are in a parallel relationship with WOM intentions. The results confirm that the green technology implemented in the tourist destination is perceived as CSR by visitors. These technologies have a positive impact on environmental sustainability and contribute to a positive tourist experience. Thus, this paper encourages social responsibility practices at tourist destinations, as well as the development of green technology. This is the first empirical study that demonstrates how the profit-related concept of CSR can be applied to nonprofit organizations, Furthermore, for the first time, the managerial concept of CSR has been reviewed with technology-based eco-innovation in a museum setting.
\end{abstract}

Keywords: corporate social responsibility; sustainable development goals (SDGs); technology-based eco-innovation; emotion; WOM intentions

\section{Introduction}

The tourism and hospitality industry is one of the driving forces in the global economy. It has many environmental and social effects [1]. Due to tourism's significant social impact, many tourism enterprises emphasize sustainable development through corporate social responsibility (CSR). CSR, despite the potential restrictions on the corporation, will eventually reap corporate benefits.

Therefore, it is not a surprise that the World Tourism Organization [2] includes among its sustainable development goals (SDGs) inclusive and sustainable economic development, sustainable consumption and production, and the sustainable use of oceans and marine resources. With this in mind, we studied museum visitors' perceptions of corporate social responsibility to reveal how museums can contribute to SDGs.

Although some scholars have defined CSR as a company's obligation to be accountable for its impact on the community and environment [3,4], CSR is defined here as a company's voluntary responsibility to the societal good, beyond its legal obligations $[5,6]$. The growing interest in CSR in environmental and societal concerns is associated with eco-innovation [7] and intensifies environmental sustainability and firms' competitiveness. 
However, neither the relationships between eco-innovation and CSR, nor its influences on tourists' behavioral intention have been explored in the tourism literature. Most studies on CSR concentrate on financial performance or employees' attitudes and behaviors [8,9]. Only a few studies have examined the precedents and ramifications of CSR [10,11]. Given the scarcity of museum studies [12], this research is the first to explore the relationship between eco-innovation and CSR in the museum context.

Eco-innovation in museums can be discussed with green technology in the context of smart tourism [13], which reduces the environmental footprint. Museum visitors' experience with eco-innovative technologies goes beyond physical experience (the economic, environmental, and social phases), and can affect the thoughts, impressions, and emotions that a visitor has during their time at a museum. In this sense, a museum that uses eco-innovation strategies such as near-field communication (NFC) or Beacon can be regarded as undertaking CSR practice both to attain environmental sustainability and to maintain competitiveness [14].

Museum visitors' perceptions of CSR and the subsequent effect on visitors' WOM intention are therefore worth investigating. The objectives of this research were to examine the relationship between visitors' perceptions of technology-based eco-innovation and CSR, and the effects on visitors' emotions and WOM intentions.

\section{Literature Review}

\subsection{NFC as a Technology-Based Eco-Innovation and Its Relation to CSR Perceptions}

CSR is a company's voluntary responsibility, and corporations, including tourist destinations, tend to undertake CSR practices. CSR has been mainly considered in economic, environmental, and governmental terms, but it also prioritizes managerial and academic functions. In the tourism industry, growing interest in CSR practices mirrors environmental and societal concerns, and CSR performance at tourist destinations is directly associated with growth in tourism. As in Fusco-Girard and Nijkamp [14], CSR practices affect destination ecology, economic prosperity, and socio-environmental compensation.

Many companies include innovations to improve performance as part of their CSR policy. According to the literature [15], museum management, museum practices, exhibition organization, and museum services directly affect visitors' perceptions of CSR. It can be assumed that a museum that uses eco-innovations will meet visitors' expectations and needs.

Rennings [7] defines eco-innovation as a process of developing new ideas or services that contribute to the reduction of the negative environmental impact; other research emphasizes $[16,17]$ that eco-innovation in the era of information technologies favors the interconnectivity between environmental performance and competitiveness, along with the reduction of environmental impact.

As Hume [17] highlights the crucial role of the information technologies in museum exhibitions, one of the most frequently used eco-innovations is near-field communication (NFC). NFC is a short-range wireless communication technology that offers electronic interaction between users and their environment; as a green technology, NFC has the potential to improve the competitiveness of a tourist destination by contributing to sustainable development, with an enhanced visitor experience and improved well-being. In this sense, museums that are using technology-based eco-innovations are engaged in CSR practices. In museum exhibitions, NFC plays an important role in visitors' enjoyment and the museum's long-term sustainability. Museums using NFC do not need to print exhibit materials, information brochures, or vouchers, so they use less paper. Venkatesh et al. [18] show how the NFC app can save 15,000 acres of forest per year if implemented in just the G8 countries.

Among the museums applying NFC technology are the Museum of London, Manchester Museum, and Horniman Museum and Gardens. The use of eco-innovations can be perceived as a CSR practice since visitors can easily see the museum's sincere interest in meeting their needs and in relationship building [19]. Visitors can also understand the museum's attempts to reduce their environmental footprint. 
Siu, Zhang, Dong, and Kwan [19] described visitors' perceptions of the new museum services in terms of novelty and meaningfulness. A museum that uses NFC is more innovative than museums that are still using brochures. Visitors can appreciate the environmental benefit of wireless technology by experiencing NFC. This study therefore hypothesizes that museum visitors are likely to perceive the implementation of NFC as CSR practice:

Hypothesis 1 (H1): Newness of NFC technology is positively associated with a museum's CSR.

Hypothesis 2 (H2): Meaningfulness of NFC technology is positively associated with a museum's CSR.

\subsection{CSR and Museum Perceived Quality, Image, and Reputation}

The perceived quality of a museum is defined as the discrepancy between the museum visitors' initial expectations and the feelings experienced from a museum service provider. Perceived quality has been investigated by various service industries as it enables retention of the relationship with customers, attracts new customers, decreases costs, increases profits, improves corporate image, and engenders positive recommendations [20]. Perceived quality is formed on the basis of technical, functional, and environmental qualities, and it is perceived by the outcome, the process-creating outcome, and the physical environment of the service. Many studies take three dimensions of perceived quality-quality experience, environment facilities, and personnel services-into consideration. Following Chen and Tseng [21], a museum's perceived quality is visitors' subjective evaluation based on goods, services, and experiences.

We suppose that while assessing museum quality with reference to CSR, visitors are likely to prefer museums that are engaged in CSR practices to museums that are not. This assumption is similar to the positive correlation between CSR and customers' service quality evaluations; a company whose behavior is perceived to be ethical earns customers' trust, which results in a better assessment of quality and services [22]. Hence, we hypothesize the following:

Hypothesis 3 (H3): CSR perceptions have a positive effect on museum perceived quality.

Aaker and Myers (1982) defined image as the net result of the interaction of a person's beliefs, ideas, feelings, and impressions of an object. The image is therefore produced by a variety of physical and behavioral attributes. The image of a company enables us to differentiate it from other companies, establish and maintain loyal relationships with stakeholders, and even obtain support from society $[23,24]$. Based on this, a museum's image is conceptualized by visitors' immediate perceptions of that museum.

Combining CSR practices with the image, CSR is likely to contribute to the formation of a positive image of a museum; Huang et al. [22] provide empirical evidence of CSR practices and a company's favorable image, demonstrating that a company's exercise of societal roles influences consumers' perception of the company's image. In the same context, this study assumes that museum visitors' perceptions of CSR are likely to influence the formation of a positive museum image. This leads to the following hypothesis:

Hypothesis 4 (H4): CSR perceptions have a positive effect on museum image.

Reputation is defined as stakeholders' evaluations of a company over time [25]. These evaluations are based on the customers' everyday impression of that company. Previous studies [25-27] show that positive organizational reputation is an important motivational factor for both employees and customers, and that corporate reputation is often evaluated by the assessment of the company's financial performance and societally responsible practices. Along with the positive relationship between CSR practices and reputation, museum reputation is defined as a representation of public opinion that responds to visitors' expectations. Based on previous studies exploring the relationship 
between CSR and reputation $[28,29]$ this study assumes that if visitors perceive a museum as adopting CSR practices, their image of that museum is likely to be more favorable, and they will evaluate a museum's reputation highly. This leads to the next hypothesis:

Hypothesis 5 (H5): CSR perceptions have a positive effect on museum reputation.

\subsection{Emotions: The Broaden-and-Build Theory of Positive Emotions}

Emotions are extensively investigated in the research on leisure and tourism [30]. Fredrickson's broaden-and-build theory claims that positive emotions broaden people's momentary thought-action repertoires and build their enduring social and psychological resources [31]. Wu and Li's study of museum quality reveals that better perceptions have a positive influence on visitors' emotions [32]. From this, we can deduce that perceived quality can enhance positive emotions and reduce negative emotions. Thus, we hypothesize the following:

Hypothesis 6 (H6): There is a positive relationship between museum perceived quality and visitors' positive emotions.

Hypothesis 7 (H7): There is a negative relationship between museum perceived quality and visitors' negative emotions.

We also suppose that visitors who have positive images of a museum are more likely to be satisfied with their visit than are visitors harboring negative images. We therefore postulate that museum image has a significant influence on visitors' emotions and hypothesize the following:

Hypothesis 8 (H8): There is a positive relationship between museum image and visitors' positive emotions.

Hypothesis 9 (H9): There is a negative relationship between museum image and visitors' negative emotions.

Studies of reputation $[26,33]$ state that a positive relationship with the consumer reputation is a strong predictor of attitude and behavior, and that positive emotion can be engendered by good reputation, simultaneously reducing negative emotions. This means that reputation improves positive emotions and mitigates negative ones. If museum visitors know that they are visiting a museum that has a good reputation, they are likely to have positive emotions about it. Based on the discussion, we state the following:

Hypothesis 10 (H10): There is a positive relationship between museum reputation and visitors' positive emotions.

Hypothesis 11 (H11): There is a negative relationship between museum reputation and visitors' negative emotions.

\subsection{Word-of-Mouth}

Word-of-mouth (WOM) is consumer-dominated informal communications, whereby individual consumers experience goods and services and evaluate their experience independent of the market $[34,35]$. Research shows that customers' emotions are significantly linked to WOM intentions, either negatively or positively [36]. Based on this, we postulate the following:

Hypothesis 12 (H12): Positive emotions positively affect WOM intention.

Hypothesis 13 (H13): Negative emotions negatively affect WOM intention. 


\section{Methodology}

\subsection{Measurements}

The measurement model was used to examine the relationship between the latent variables and their corresponding items [37]. The characteristics of CSR perception and perceived qualities in this study are conceptualized as the second-order level of abstraction and reflective constructs. Based on the previous study, measuring the construct of CSR, we highlighted three dimensions: economic, social, and environmental. Measuring NFC dimensions and CSR perceptions, previous studies $[19,22,28,38-40]$ were studied and 50 measurement items were adopted. The constructs relevant to manifest these concepts are newness, meaningfulness, CSR perceptions, perceived quality, image, reputation, positive emotions, negative emotions, and WOM intention, which were adapted from past studies and modified for the research model and the context. Given the difficulty of bundling all items through a unidimensional latent variable and the possibility of measurement error in the resultant construct [41,42], we used higher-order modeling, where the contribution of each dimension to a higher-level construct could be assessed and delineated.

All items were measured on a seven-point Likert scale ranging from strongly disagree (1) to strongly agree (7). Moreover, 10 items of demographic variables were measured on the nominal scale. Three academic experts were invited to verify the validity of the preliminary items, and modifications were made accordingly.

\subsection{Data Collection}

Handok Museum in South Korea was the research site for this study. The museum is renowned for its socially responsible practices and green technologies such as NFC and Beacon. The data were collected via on-site surveys conducted among Handok Museum visitors who used NFC or Beacon while there. Only 250 questionnaires were collected during the survey period. The location of the museum and undeveloped transportation might explain the small number of visitors. All questionnaires were examined, all invalid data were removed, and a final sample of 161 questionnaires was used for the analysis.

\section{Data Analysis and Results}

\subsection{Data Analysis}

We used several statistical techniques to analyze the data. The research model was tested using structural equation modeling. All descriptive statistics were analyzed through SPSS 21, and the hypotheses were tested via a partial least squares (PLS) method using the PLS-Graph 3.0 program. PLS is one of the most widely used analytical techniques. As PLS estimates the model parameters minimizing the residual variance of the dependent variables, and does not require any parametric conditions or a large sample size, it was well suited to this study.

\subsection{Respondent Profile}

Table 1 shows the demographic characteristics of the respondents $(n=132)$. There were slightly more female than male participants: $94(58.4 \%)$ and $67(41.6 \%)$, respectively. The largest percentage of respondents $(82 \%)$ was $20-29$ years old. A majority of the respondents $(n=129,80.1 \%)$ graduated from two-year colleges. Single people $(n=131 / 81.4 \%)$ greatly outnumbered married people and those who chose not to respond $(n=30 / 18.6 \%)$. Most of the respondents were students $(n=134 / 83.2 \%)$, and, predictably, the largest group $(n=125 / 77.6 \%)$ had an average monthly income of less than one million Korean won (USD835). The proportion of respondents who had previously used NFC ( $n=86 /$ $53.4 \%)$ was quite similar to the proportion of those who had not $(n=74 / 46.0)$. Most respondents, however $(n=133 / 82.6 \%)$, reported that they had never used Beacon before. 
Table 1. Demographic characteristics of the respondents.

\begin{tabular}{|c|c|c|c|}
\hline \multicolumn{2}{|c|}{ Characteristics } & \multirow{2}{*}{$\begin{array}{c}\text { Frequency } \\
67\end{array}$} & \multirow{2}{*}{$\begin{array}{c}\% \\
41.6\end{array}$} \\
\hline Gender & Male & & \\
\hline & Female & 94 & 58.4 \\
\hline \multirow{6}{*}{ Age } & Under 20 & 1 & 0.6 \\
\hline & $20-29$ & 132 & 82.0 \\
\hline & $30-39$ & 8 & 5.0 \\
\hline & $40-49$ & 8 & 5.0 \\
\hline & $50-59$ & 5 & 3.1 \\
\hline & Over 60 & 7 & 4.3 \\
\hline \multirow{4}{*}{ Education } & Middle and high school & 8 & 5.0 \\
\hline & Two-year college & 129 & 80.1 \\
\hline & University & 14 & 8.7 \\
\hline & Graduate school & 10 & 6.2 \\
\hline \multirow{3}{*}{ Marital Status } & Married & 24 & 14.9 \\
\hline & Single & 131 & 81.4 \\
\hline & No answer & 6 & 3.7 \\
\hline \multirow{6}{*}{ Occupation } & Student & 134 & 83.2 \\
\hline & Office worker & 4 & 2.5 \\
\hline & Services & 2 & 1.2 \\
\hline & Technician & 3 & 1.9 \\
\hline & Professional & 8 & 5.0 \\
\hline & Homemaker & 10 & 6.2 \\
\hline \multirow{7}{*}{ Monthly Income } & Less than 1 million won* & 125 & 77.6 \\
\hline & 1-1.9 million won & 15 & 9.3 \\
\hline & 2-2.9 million won & 5 & 3.1 \\
\hline & 3-3.9 million won & 6 & 3.7 \\
\hline & 4-4.9 million won & 3 & 1.9 \\
\hline & Over 5 million won & 3 & 1.9 \\
\hline & No answer & 4 & 2.5 \\
\hline \multirow{3}{*}{ NFC Experience } & Yes & 86 & 53.4 \\
\hline & No & 74 & 46.0 \\
\hline & No answer & 1 & 0.6 \\
\hline \multirow{4}{*}{ Beacon Experience } & Yes & 23 & 14.3 \\
\hline & No & 133 & 82.6 \\
\hline & No answer & 5 & 3.1 \\
\hline & Total & 161 & 100.0 \\
\hline
\end{tabular}

* Note: 1 U.S. dollar $=1100$ Korean won.

\subsection{Measurement Model}

The measurement model was assessed to confirm the reliability and validity of the research model. Table 2 shows that all standardized loadings are above the minimal threshold of 0.70 and are statistically significant at $p<0.05$. Table 3 shows that all of the constructs in the model satisfied the reliability requirements, with a composite reliability greater than 0.70 , and the discriminant validity requirements, with an average variance extracted (AVE) greater than 0.50. Finally, Cronbach's $\alpha$ for all constructs exceeded the minimal threshold of 0.70 . Additionally, as can be seen from Table 4 , the square 
root of the AVE of each construct was greater than the squared correlations of other constructs [43]. Thus, the reliability and discriminant and convergent validity were supported.

Table 2. Standardized loadings of the constructs.

\begin{tabular}{|c|c|c|c|c|}
\hline Constructs & & Measured Items & Std. Loadings & $t$-Value \\
\hline \multirow[t]{5}{*}{ Newness } & NEW 1 & $\begin{array}{l}\text { Exhibition services facilitated with NFC and Beacon } \\
\text { technologies at Handok Museum are novel. }\end{array}$ & 0.865 & 40.72 \\
\hline & NEW 2 & $\begin{array}{l}\text { Exhibition services facilitated with NFC and Beacon } \\
\text { technologies at Handok Museum are innovative. }\end{array}$ & 0.873 & 37.759 \\
\hline & NEW 3 & $\begin{array}{l}\text { Exhibition services facilitated with NFC and Beacon } \\
\text { technologies at Handok Museum are creative. }\end{array}$ & 0.874 & 39.963 \\
\hline & NEW 4 & $\begin{array}{l}\text { Exhibition services facilitated with NFC and Beacon } \\
\text { technologies at Handok Museum differ significantly } \\
\text { from other museums in terms of ways of providing } \\
\text { explanations about an exhibition. }\end{array}$ & 0.792 & 18.641 \\
\hline & NEW 5 & $\begin{array}{l}\text { Exhibition services facilitated with NFC and Beacon } \\
\text { technologies at Handok Museum are exceptional. }\end{array}$ & 0.859 & 30.366 \\
\hline \multirow[t]{6}{*}{ Meaningfulness } & MEAN 1 & $\begin{array}{l}\text { Exhibition services facilitated with NFC and Beacon } \\
\text { technologies at Handok Museum offer unique } \\
\text { advantages to the visitors. }\end{array}$ & 0.841 & 29.529 \\
\hline & MEAN 2 & $\begin{array}{l}\text { Exhibition services facilitated with NFC and Beacon } \\
\text { technologies at Handok Museum offer higher-quality } \\
\text { exhibition services than other museums. }\end{array}$ & 0.802 & 15.079 \\
\hline & MEAN 3 & $\begin{array}{l}\text { Exhibition services facilitated by NFC and Beacon } \\
\text { technologies at Handok Museum offer higher value } \\
\text { exhibition services than other museums. }\end{array}$ & 0.857 & 41.609 \\
\hline & MEAN 4 & $\begin{array}{l}\text { Exhibition services facilitated with NFC and Beacon } \\
\text { technologies at Handok Museum solve visitors' } \\
\text { problems related to the exhibition. }\end{array}$ & 0.759 & 13.411 \\
\hline & MEAN 5 & $\begin{array}{l}\text { Exhibition services facilitated with NFC and Beacon } \\
\text { technologies at Handok Museum allow museum } \\
\text { visitors to understand the exhibition simply. }\end{array}$ & 0.838 & 25.593 \\
\hline & MEAN 6 & $\begin{array}{l}\text { Exhibition services facilitated with NFC and Beacon } \\
\text { technologies at Handok Museum provide a lot of } \\
\text { benefits to the visitors. }\end{array}$ & 0.683 & 10.14 \\
\hline \multirow[t]{6}{*}{$\begin{array}{l}\text { Corporate Social } \\
\text { Responsibility }\end{array}$} & Eco_CSR 1 & $\begin{array}{l}\text { Providing exhibition services via technologies such as } \\
\text { NFC/Beacon, Handok Museum provides services } \\
\text { necessary to the country. }\end{array}$ & 0.833 & 27.776 \\
\hline & Eco_CSR 2 & $\begin{array}{l}\text { Providing exhibition services via technologies such as } \\
\text { NFC/Beacon, Handok Museum contributes to the } \\
\text { economic development through re-investing profits. }\end{array}$ & 0.855 & 38.413 \\
\hline & Eco_CSR 3 & $\begin{array}{l}\text { Providing exhibition services via technologies such as } \\
\text { NFC/Beacon, Handok Museum is operationalized } \\
\text { effectively. }\end{array}$ & 0.862 & 33.457 \\
\hline & Env_CSR 1 & $\begin{array}{l}\text { Providing exhibition services via technologies such as } \\
\text { NFC/Beacon, Handok Museum provides eco-friendly } \\
\text { exhibition services that are different from ones } \\
\text { provided by the museums using paper pamphlets. }\end{array}$ & 0.891 & 45.849 \\
\hline & Env_CSR 2 & $\begin{array}{l}\text { Providing exhibition services via technologies such as } \\
\text { NFC/Beacon, Handok Museum seems to take } \\
\text { responsibility for environmental protection since it } \\
\text { prevents excessive use of natural resources. }\end{array}$ & 0.925 & 65.316 \\
\hline & Env_CSR 3 & $\begin{array}{l}\text { Providing exhibition services via technologies such as } \\
\text { NFC/Beacon, Handok Museum tries to reduce its } \\
\text { negative environmental impact through replacing } \\
\text { paper pamphlets. }\end{array}$ & 0.894 & 33.904 \\
\hline
\end{tabular}


Table 2. Cont.

\begin{tabular}{|c|c|c|c|c|}
\hline Constructs & & Measured Items & Std. Loadings & $t$-Value \\
\hline \multirow[t]{5}{*}{$\begin{array}{l}\text { Corporate Social } \\
\text { Responsibility }\end{array}$} & Env_CSR 4 & $\begin{array}{l}\text { Providing exhibition services via technologies such as } \\
\text { NFC/Beacon, Handok Museum reduces the negative } \\
\text { environmental impact as much as possible through } \\
\text { reducing the use of paper pamphlets. }\end{array}$ & 0.903 & 46.346 \\
\hline & Soc_CSR 1 & $\begin{array}{l}\text { Providing exhibition services via technologies such as } \\
\text { NFC/Beacon, Handok Museum makes various social } \\
\text { contributions via providing an exhibition experience. }\end{array}$ & 0.908 & 64.606 \\
\hline & Soc_CSR 2 & $\begin{array}{l}\text { Providing exhibition services via technologies such as } \\
\text { NFC/Beacon, Handok Museum contributes in different } \\
\text { ways to the local community via providing an } \\
\text { exhibition experience. }\end{array}$ & 0.899 & 44.072 \\
\hline & Soc_CSR 3 & $\begin{array}{l}\text { Providing exhibition services via technologies such as } \\
\text { NFC/Beacon, Handok Museum has a positive } \\
\text { influence on the community, providing an exhibition } \\
\text { experience. }\end{array}$ & 0.927 & 80.015 \\
\hline & Soc_CSR 4 & $\begin{array}{l}\text { Providing exhibition services via technologies such as } \\
\text { NFC/Beacon, Handok Museum focuses not only on } \\
\text { economic profits but also plays an important social } \\
\text { role. }\end{array}$ & 0.878 & 37.096 \\
\hline \multirow[t]{11}{*}{$\begin{array}{l}\text { Museum } \\
\text { Perceived } \\
\text { Quality }\end{array}$} & QUAL 1 & $\begin{array}{l}\text { Handok Museum provides medicine-related scientific } \\
\text { knowledge. }\end{array}$ & 0.809 & 21.663 \\
\hline & QUAL 2 & $\begin{array}{l}\text { Handok Museum continues to update the museum's } \\
\text { facilities. }\end{array}$ & 0.82 & 26.812 \\
\hline & QUAL 3 & $\begin{array}{l}\text { Handok Museum organizes experience activities or } \\
\text { programs. }\end{array}$ & 0.726 & 10.946 \\
\hline & QUAL 4 & Handok Museum provides high-quality experiences. & 0.898 & 58.689 \\
\hline & QUAL 5 & $\begin{array}{l}\text { Handok Museum provides different exhibition } \\
\text { services using media resources. }\end{array}$ & 0.817 & 24.407 \\
\hline & ENV 1 & Handok Museum provides a good atmosphere. & 0.929 & 47.685 \\
\hline & ENV 2 & Handok Museum provides good quality facilities. & 0.942 & 68.359 \\
\hline & ENV 3 & Handok Museum keeps the environment clean. & 0.933 & 52.503 \\
\hline & PERS 1 & $\begin{array}{l}\text { Staff at Handok Museum have confidence and } \\
\text { professional knowledge. }\end{array}$ & 0.847 & 29.131 \\
\hline & PERS 2 & $\begin{array}{l}\text { Staff at Handok Museum can efficiently handle } \\
\text { customer complaints. }\end{array}$ & 0.862 & 33.372 \\
\hline & PERS 3 & Staff at Handok Museum provides friendly service. & 0.913 & 67.833 \\
\hline \multirow[t]{4}{*}{ Museum Image } & IMG 1 & I have a good impression of Handok Museum. & 0.845 & 13.939 \\
\hline & IMG 2 & Handok Museum is trustworthy. & 0.917 & 61.723 \\
\hline & IMG 3 & $\begin{array}{l}\text { Handok Museum has a better reputation than the } \\
\text { other medical museums. }\end{array}$ & 0.896 & 35.613 \\
\hline & IMG 4 & I have a good overall image of Handok Museum. & 0.904 & 49.977 \\
\hline \multirow[t]{4}{*}{$\begin{array}{l}\text { Museum } \\
\text { Reputation }\end{array}$} & MR 1 & $\begin{array}{l}\text { I think that Handok Museum's management system is } \\
\text { good. }\end{array}$ & 0.879 & 38.417 \\
\hline & MR 2 & $\begin{array}{l}\text { I think that Handok Museum provides the most } \\
\text { innovative exhibition guidance services. }\end{array}$ & 0.91 & 45.388 \\
\hline & MR 3 & I think that Handok Museum has the potential to grow. & 0.891 & 39.934 \\
\hline & MR 4 & $\begin{array}{l}\text { I think that Handok Museum provides high-quality } \\
\text { exhibition services via innovative technologies. }\end{array}$ & 0.914 & 54.601 \\
\hline \multirow[t]{3}{*}{$\begin{array}{l}\text { Positive } \\
\text { Emotions }\end{array}$} & POS 1 & The visit to Handok Museum made me happy. & 0.921 & 63.831 \\
\hline & POS 2 & The visit to Handok Museum made me joyful. & 0.902 & 45.599 \\
\hline & POS 3 & The visit to Handok Museum delighted me. & 0.898 & 34.571 \\
\hline
\end{tabular}


Table 2. Cont.

\begin{tabular}{lllll}
\hline Constructs & & Measured Items & Std. Loadings & $t$-Value \\
\hline $\begin{array}{l}\text { Negative } \\
\text { Emotions }\end{array}$ & NEG 1 & The visit to Handok Museum made me upset. & 0.874 & 27.284 \\
\hline & NEG 2 & The visit to Handok museum made me nervous. & 0.94 & 61.903 \\
\hline NEG 3 & The visit to Handok museum made me angry. & 0.867 & 16.946 \\
\hline $\begin{array}{l}\text { Word-of-Mouth } \\
\text { Intention }\end{array}$ & WOM 1 & I want to recommend Handok Museum to others. & 0.954 & 98.54 \\
\hline & WOM 2 & $\begin{array}{l}\text { I want to encourage my friends or relatives to visit } \\
\text { Handok Museum. }\end{array}$ & 0.951 & 95.197 \\
\hline & WOM 3 & $\begin{array}{l}\text { I want to spread positive word-of-mouth about the } \\
\text { experience I had at Handok Museum. }\end{array}$ & 0.942 & 72.047 \\
\hline
\end{tabular}

Table 3. Descriptive statistics of the constructs.

\begin{tabular}{|c|c|c|c|c|c|c|}
\hline \multicolumn{2}{|r|}{ Construct } & $\begin{array}{l}\text { Composite } \\
\text { Reliability }\end{array}$ & AVE & Cronbach's $\alpha$ & Mean & STD \\
\hline \multicolumn{2}{|r|}{ Newness } & 0.930 & 0.728 & 0.906 & 5.390 & 1.08 \\
\hline \multicolumn{2}{|c|}{ Meaningfulness } & 0.916 & 0.687 & 0.886 & 5.320 & 0.97 \\
\hline \multirow{3}{*}{ CSR } & Economic CSR & 0.887 & 0.723 & 0.807 & 5.050 & 0.94 \\
\hline & Environmental CSR & 0.946 & 0.816 & 0.925 & 5.621 & 1.05 \\
\hline & Social CSR & 0.947 & 0.816 & 0.924 & 5.366 & 1.03 \\
\hline \multirow{3}{*}{$\begin{array}{l}\text { Perceived } \\
\text { quality }\end{array}$} & Quality experience & 0.908 & 0.666 & 0.872 & 5.448 & 0.88 \\
\hline & Facilities & 0.954 & 0.873 & 0.927 & 6.008 & 0.98 \\
\hline & Personnel services & 0.907 & 0.764 & 0.844 & 5.271 & 1.03 \\
\hline & Image & 0.939 & 0.794 & 0.913 & 5.627 & 0.99 \\
\hline \multicolumn{2}{|r|}{ Reputation } & 0.944 & 0.808 & 0.921 & 5.742 & 1.02 \\
\hline \multicolumn{2}{|c|}{ Positive emotions } & 0.933 & 0.822 & 0.892 & 5.240 & 1.03 \\
\hline \multicolumn{2}{|c|}{ Negative emotions } & 0.923 & 0.800 & 0.872 & 2.232 & 1.17 \\
\hline \multicolumn{2}{|r|}{ WOM } & 0.964 & 0.900 & 0.944 & 5.400 & 1.08 \\
\hline
\end{tabular}


Table 4. Correlation among constructs.

\begin{tabular}{|c|c|c|c|c|c|c|c|c|c|c|c|c|c|}
\hline Constructs & 1 & 2 & 3 & 4 & 5 & 6 & 7 & 8 & 9 & 10 & 11 & 12 & 13 \\
\hline 1. NEW & 0.853 & & & & & & & & & & & & \\
\hline 2. MEAN & $0.661^{* *}$ & 0.829 & & & & & & & & & & & \\
\hline 3. Eco_CSR & $0.569^{* *}$ & $0.570^{* *}$ & 0.850 & & & & & & & & & & \\
\hline 4. Env_CSR & $0.532^{* *}$ & $0.598^{* *}$ & $0.562^{* *}$ & 0.903 & & & & & & & & & \\
\hline 5. Soc_CSR & $0.538^{* *}$ & $0.598^{* *}$ & $0.620^{* * *}$ & $0.624^{* *}$ & 0.903 & & & & & & & & \\
\hline 6. QUAL & $0.598^{* *}$ & $0.644^{* *}$ & $0.663^{* * *}$ & $0.673^{* *}$ & 0 & 0.816 & & & & & & & \\
\hline 7. ENV & $0.528^{* *}$ & $0.548^{* *}$ & $0.581^{* *}$ & $0.652^{* *}$ & $0.652^{* *}$ & $0.705^{* *}$ & 0.934 & & & & & & \\
\hline 8. PERS & $0.358^{* *}$ & $0.502^{* *}$ & $0.539^{* *}$ & $0.554^{* *}$ & $0.532^{* *}$ & $0.624^{* *}$ & $0.635^{* *}$ & 0.874 & & & & & \\
\hline 9. IMG & $0.613^{* *}$ & $0.626^{* *}$ & $0.539^{* *}$ & $0.533^{* *}$ & $0.612^{* *}$ & $0.559^{* *}$ & $0.620^{* *}$ & $0.504^{* *}$ & 0.891 & & & & \\
\hline 10. REP & $0.629^{* *}$ & $0.648^{* *}$ & $0.566^{* *}$ & $0.644^{* *}$ & $0.669^{* *}$ & $0.664^{* *}$ & $0.685^{* *}$ & $0.486^{* *}$ & $0.787^{* *}$ & 0.899 & & & \\
\hline 11. POS & $0.538^{* *}$ & $0.540^{* *}$ & $0.489^{* *}$ & $0.423^{* *}$ & $0.535^{* *}$ & $0.524^{* * *}$ & $0.464^{* *}$ & $0.461^{* *}$ & $0.646^{* *}$ & $0.585^{* *}$ & 0.907 & & \\
\hline 12. NEG & $-0.268^{* * *}$ & $-0.344^{* *}$ & $-0.357^{* *}$ & $-0.249^{* *}$ & $-0.303^{* *}$ & $-0.223^{* *}$ & $-0.319^{* *}$ & $-0.187^{*}$ & $-0.454^{* *}$ & $-0.415^{* *}$ & $-0.284^{* *}$ & 0.894 & \\
\hline 13.WOM & $0.492^{* *}$ & $0.589^{* *}$ & $0.513^{* *}$ & $0.542^{* *}$ & $0.612^{* *}$ & $0.564^{* *}$ & $0.557^{* *}$ & $0.471^{* *}$ & $0.725^{* *}$ & $0.696^{* *}$ & $0.677^{* *}$ & $-0.331^{* *}$ & 0.949 \\
\hline
\end{tabular}

Note: The diagonal elements in bold in the "correlation of constructs" matrix are the square root of the average variance extracted (AVE). According to Bhattacherjee and Sanford (2006,

p. 815), "for adequate discriminant validity, diagonal elements should be greater than their corresponding off-diagonal elements." ${ }^{* *}$ significance at $p<0.1$. 


\subsection{Structural Model and Hypothesis Testing}

The structural model was assessed to test the hypotheses. The explanatory power and path significance of the structural model were evaluated using a bootstrapping technique. The results reveal that eco-innovation is positively related with CSR perceptions, which influence WOM intention via visitors' cognition of museum characteristics and emotions. The results are shown in Figure 1 and Table 5 .

Table 5. Standardized structural estimates and hypotheses tests.

\begin{tabular}{clccc}
\hline Hypothesis & \multicolumn{1}{c}{ Path } & Estimates & $\boldsymbol{t}$-Value & Results \\
\hline $\mathrm{H}_{1}$ & Newness $\rightarrow$ CSR perceptions & 0.326 & 4.862 & Supported \\
\hline $\mathrm{H}_{2}$ & Meaningfulness $\rightarrow$ CSR perceptions & 0.470 & 6.917 & Supported \\
\hline $\mathrm{H}_{3}$ & CSR perceptions $\rightarrow$ Museum perceived quality & 0.817 & 21.666 & Supported \\
\hline $\mathrm{H}_{4}$ & CSR perceptions $\rightarrow$ Museum image & 0.656 & 10.926 & Supported \\
\hline $\mathrm{H}_{5}$ & CSR perceptions $\rightarrow$ Museum reputation & 0.738 & 13.438 & Supported \\
\hline $\mathrm{H}_{6}$ & Museum perceived quality $\rightarrow$ Positive emotions & 0.199 & 2.137 & Supported \\
\hline $\mathrm{H}_{7}$ & Museum perceived quality $\rightarrow$ Negative emotions & 0.094 & 0.698 & Rejected \\
\hline $\mathrm{H}_{8}$ & Museum image $\rightarrow$ Positive emotions & 0.447 & 5.886 & Supported \\
\hline $\mathrm{H}_{9}$ & Museum image $\rightarrow$ Negative emotions & -0.361 & 3.303 & Supported \\
\hline $\mathrm{H}_{10}$ & Museum reputation $\rightarrow$ Positive emotions & 0.098 & 0.958 & Rejected \\
\hline $\mathrm{H}_{11}$ & Museum reputation $\rightarrow$ Negative emotions & -0.203 & 1.658 & Supported \\
\hline $\mathrm{H}_{12}$ & Positive emotions $\rightarrow$ WOM intention & 0.635 & 9.344 & Supported \\
\hline $\mathrm{H}_{13}$ & Negative emotions $\rightarrow$ WOM intention & -0.151 & 2.153 & Supported \\
\hline
\end{tabular}

H1 and H2 address the structural relationships between technology-based eco-innovation's dimensions such as newness and meaningfulness and CSR perceptions. Both hypotheses are supported, revealing significant, positive relationships between eco-innovation and CSR: newness has a direct impact on perceptions of CSR $(\beta=0.322, p<0.001)$, and meaningfulness has a direct impact on perceptions of CSR $(\beta=0.479, p<0.001)$.

$\mathrm{H} 3, \mathrm{H} 4$, and $\mathrm{H} 5$ are concerned with the relationships between CSR perceptions and museum characteristics such as perceived quality, image, and reputation. The hypotheses indicate that CSR perceptions have a positive effect on a museum's perceived quality $(\beta=0.817, p<0.001)$, image $(\beta=0.656, p<0.001)$, and reputation $(\beta=0.738, p<0.001)$. Therefore, all three hypotheses are supported.

$\mathrm{H} 6, \mathrm{H} 8$, and $\mathrm{H} 10$ address the relationships between visitors' perceptions of museum characteristics and visitors' positive emotions; $\mathrm{H} 7, \mathrm{H} 9$, and $\mathrm{H} 11$ address the relationships between visitors' perceptions about museum characteristics and visitors' negative emotions. Although museum perceived quality has a significantly positive influence on positive emotions $(\beta=0.199, p<0.05)$, it does not have a significant influence on negative emotions $(\beta=0.094$, non-significant): H6 is therefore supported and H7 is rejected. Museum image has a significantly positive influence on positive emotions $(\beta=0.447$, $p<0.001)$ and a significantly negative influence on negative emotions $(\beta=-0.361, p<0.001)$, thus supporting $\mathrm{H} 8$ and $\mathrm{H} 9$. In turn, museum reputation does not have a significant influence on positive emotions ( $\beta=0.098$, non-significant), but does have a significantly negative influence on negative emotions $(\beta=-0.203, p<0.1)$. Consequently, H10 is rejected and H11 is supported.

Finally, H12 and H13 are concerned with the relationships between the emotions and WOM intention of museum visitors. Obviously, positive emotions are positively related to WOM intentions $(\beta=0.635, p<0.001)$, while negative emotions are negatively related to WOM intention $(\beta=-0.151$, $p<0.01)$. Therefore, both hypotheses are supported. 


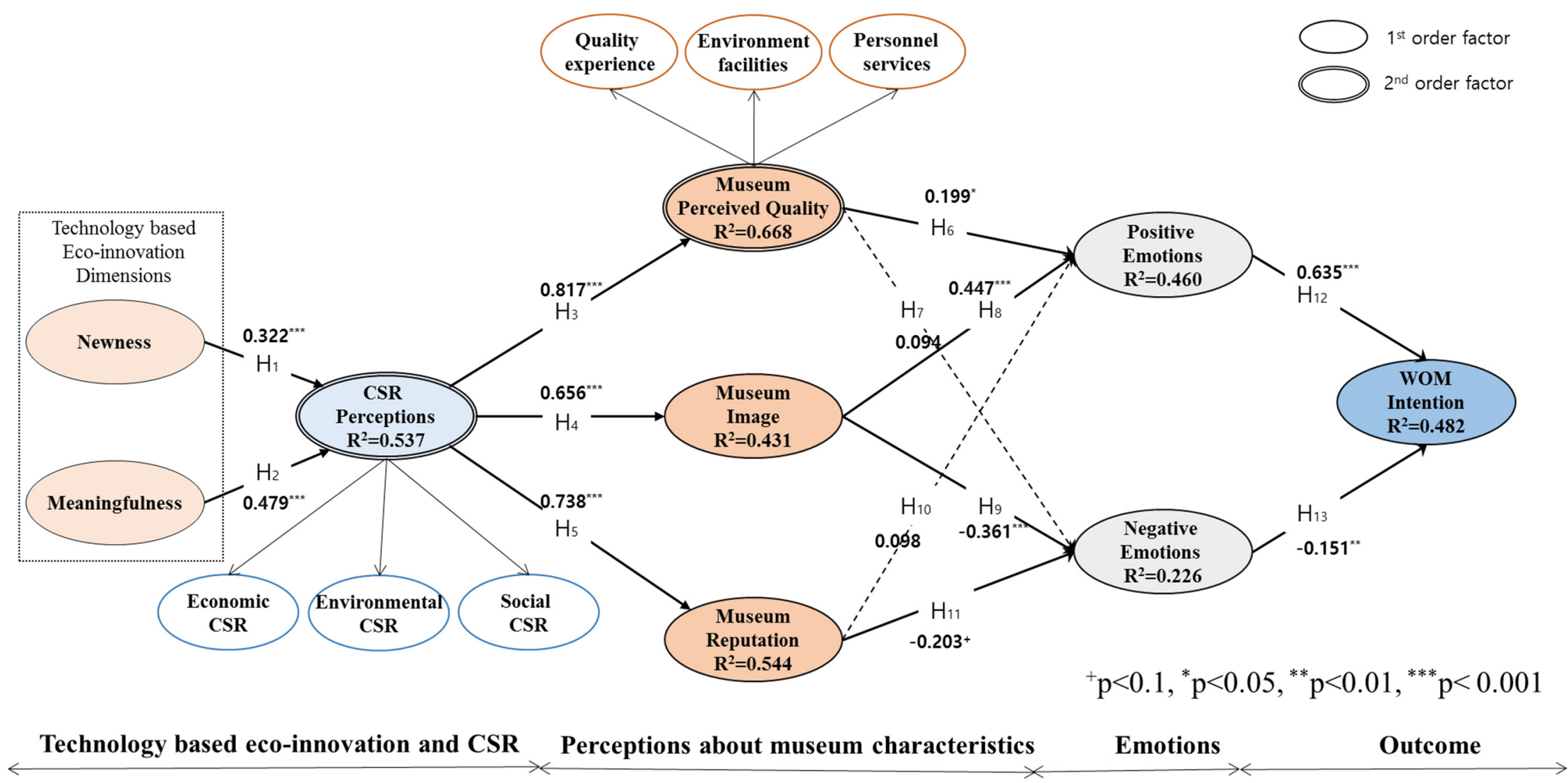

Figure 1. The estimated structural model. 


\section{Discussion and Conclusions}

This research views NFC/Beacon as a technology-based eco-innovation and has demonstrated that green technology directly and positively influences visitors' perceptions of CSR practices. Museum visitors' perceptions of CSR are assessed in terms of newness and meaningfulness, both of which are important dimensions of eco-innovation. This study has also confirmed the positive influence of CSR on perceived quality, image, and reputation. as in prior studies, the result indicates that museum visitors evaluate a museum's image and reputation in terms of CSR practices, so CSR is important for forming a positive image and confirming the good reputation of public venues.

It is interesting that this study reveals results that contradict the findings of $\mathrm{Wu}$ and $\mathrm{Li}$ [32] on the relationships between museum characteristics and visitors' emotions. The result shows that perceived quality is related only to positive emotions, but not to negative ones, as supported by Jang and Namkung [44].

Furthermore, this study has found that a museum's reputation has a significant effect on negative emotions, but not positive ones. This result only partially supports an earlier study of the significant relationships between reputation and positive/negative emotions.

A museum's perceived quality and reputation are only partially related to museum emotion. The museum image shows a significantly parallel relationship to positive and negative emotions; image has either a significantly positive influence on positive emotions or a significantly negative influence on negative emotions. Therefore, image is the most influential determinant of visitors' emotions.

Finally, the results pertaining to the relationships between emotions and WOM intention are consistent with the findings of previous research [19], revealing a positive relationship between positive emotions and WOM intention, but a negative relationship between negative emotions and WOM intention.

This study is noteworthy in that not many studies have found a positive relationship between eco-innovation and CSR. Very few studies have empirically explored this relationship.

Furthermore, CSR has been studied primarily in terms of a company's management issues. However, this study looks at CSR practices, from the corporate managerial level to the public setting like museums, by applying the corporate concept of CSR to nonprofit organizations; therefore, we extend the domain of CSR practice from private to public organizations. In addition to broadening the concept of CSR, this paper has applied a management perspective to the information technology perspective (e.g., smart tourism) by incorporating the concept of eco-innovation into CSR (e.g., technology-based NFC/Beacon).

\section{Implications and Limitations}

This study makes considerable theoretical and practical contributions as one of the few studies that has empirically explored the relationship between eco-innovative NFC/Beacon technologies and CSR perceptions. It makes a contribution to the theory by providing more knowledge about the major determinants of CSR perceptions. It also extends the domains of smart tourism and sustainable tourism by elucidating the crucial role of technology-based eco-innovations in creating a competitive and attractive tourist destination.

Moreover, this study presents one example of how a tourist destination like a museum can contribute to SDGs. Museums with eco-innovations have a positive social impact and ensure sustainable consumption. Furthermore, this research confirms the importance of emotions in the tourism industry, emphasizing that positive emotions favorably affect WOM intention.

In terms of practical contributions, this study's findings encourage companies and tourist destinations to embrace their social responsibilities and to orient their policies and strategies to CSR. In addition, this study contributes to the further development of green technologies and its worldwide use at other tourist destinations.

Despite these important contributions, our study has several limitations. The major drawbacks are the context and samples of the study: the data come from a single museum, and most of the 
study participants were students. Obviously, it is difficult to generalize from these findings. Thus, future research should follow up on the relationship between eco-innovation and CSR. We suggest that future studies investigate the relationship between eco-innovations and perceptions of CSR in other contexts, concentrating on demographic peculiarities in the sample. In addition, we suggest interviewing respondents to validate and support the results of this study. We also suggest comparing domestic and international tourists' perceptions of CSR.

Author Contributions: N.C. conceived and designed the experiments; I.T. performed the experiments and analyzed the data; N.C., I.T. and S.J.L. wrote and revised the paper. All of the authors contributed to read and approved the final manuscript.

Funding: This work was supported by the Ministry of Education of the Republic of Korea and the National Research Foundation of Korea (NRF-2016S1A3A2925146).

Conflicts of Interest: The authors declare no conflict of interest.

\section{References}

1. Jones, P.; Hillier, D.; Comfort, D. The sustainable development goals and the tourism and hospitality industry. Athens J. Tour. 2017, 4, 7-18. [CrossRef]

2. World Tourism Organization. Tourism and the Sustainable Development Goals; UNWTO: Madrid, Spain, 2015. [CrossRef]

3. Frederick, W.; Post, J.; Davis, K.E. Business and Society. Corporate Strategy, Public Policy, Ethics, 7th ed.; McGraw-Hill: London, UK, 1992.

4. Marsden, C. The Role of Public Authorities in Corporate Social Responsibility. 2001. Available online: http://www.alter.be/socialresponsibility/people/marchri/en/displayPerson (accessed on 23 June 2003).

5. McWilliams, A.; Siegel, D. Corporate Social Responsibility: A Theory of the Firm Perspective. Acad. Manag. Rev. 2001, 26, 117-127. [CrossRef]

6. Dahlsrud, A. How Corporate Social Responsibility Is Defined: An Analysis of 37 Definitions. Corp. Soc. Responsib. Environ. Manag. 2008, 15, 1-13. [CrossRef]

7. Rennings, K. Redefining innovation-Eco-innovation research and the contribution from ecological economics. Ecol. Econ. 2000, 32, 319-332. [CrossRef]

8. Luo, X.; Bhattacharya, C.B. Corporate social responsibility, customer satisfaction, and market value. J. Mark. 2006, 70, 1-18. [CrossRef]

9. Campbell, J.L. Why would corporations behave in socially responsible ways? An institutional theory of corporate social responsibility. Acad. Manag. Rev. 2007, 32, 946-967. [CrossRef]

10. Martínez, P.; Bosque, I.R. CSR and customer loyalty: The roles of trust, customer identification with the company and satisfaction. Int. J. Hosp. Manag. 2013, 35, 89-99. [CrossRef]

11. Henderson, J.C. Corporate social responsibility and tourism: Hotel companies in Phuket, Thailand, after the Indian Ocean tsunami. Int. J. Hosp. Manag. 2007, 26, 228-239. [CrossRef]

12. Chan, J.; Kim, L. The Consumption of Museum Service Experiences: Benefits and Value of Museum Experiences. J. Hosp. Mark. Manag. 2009, 18, 173-196.

13. Gretzel, U.; Koo, C.; Sigala, M.; Xiang, Z. Special Issue on Smart Tourism: Convergence of Information Technologies, Experiences, and Theories. Electron. Mark. 2015, 25, 175-177. [CrossRef]

14. Fusko-Girard, L.; Nijkamp, P. Narrow Escapes: Pathways to Sustainable Local Cultural Tourism. In Cultural Tourism and Sustainable Local Development; Fusco-Girard, L., Nijkamp, P., Eds.; Ashgate: Farnham, UK, 2009; pp. 1-9.

15. Ellen, P.S.; Webb, D.J.; Mohr, L.A. Building corporate associations: Consumer attributions for corporate socially responsible programs. J Acad. Mark. Sci. 2006, 34, 147-157. [CrossRef]

16. Kesidou, E.; Demirel, P. On the Drivers of Eco-Innovations: Empirical Evidence from the UK. Res. Policy 2012, 41, 862-870. [CrossRef]

17. Hume, M. To Technovate or Not to Technovate? Examining the Inter-Relationship of Consumer Technology, Museum Service Quality, Museum Value, and Repurchase Intent. J. Nonprofit Public Sect. Mark. 2015, 27, 155-182. [CrossRef] 
18. Venkatesh, V.; Nithya, C.H.; Surhonne, A.P. An NFC based Innovation for Paperless Retail Transactions and Digital Receipts Management. In Proceedings of the 2015 Annual IEEE India Conference (INDICON), New Delhi, India, 17-20 December 2015.

19. Siu, N.; Zhang, T.; Dong, P.; Kwan, H.Y. New Service Bonds and Customer Value in Customer Relationship Management: The Case of Museum Visitors. Tour. Manag. 2013, 36, 293-303. [CrossRef]

20. Hsieh, C.M.; Park, S.H.; Hitchcock, M. Examining the Relationships among Motivation, Service Quality and Loyalty: The Case of the National Museum of Natural Science. Asia Pac. J. Tour. Res. 2015, 20, 1505-1526. [CrossRef]

21. Chen, C.F.; Tseng, W.S. Exploring Customer-Based Airline Brand Equity: Evidence from Taiwan. Transp. J. 2010, 29, 24-34.

22. Huang, C.C.; Yen, S.W.; Liu, C.Y.; Huang, P.C. The Relationship among Corporate Social Responsibility, Service Quality, Corporate Image and Purchase Intention. Int. J. Organ. Innov. 2014, 6, 68-84.

23. Nguyen, N.; Leblanc, G. Corporate Image and Corporate Reputation in Customers Retention Decisions in Services. J. Retail. Consum. Serv. 2001, 8, 227-236. [CrossRef]

24. Chen, Y.S. The Driver of Green Innovation and Green Image-Green Core Competence. J. Bus. Ethics. 2008, 81, 531-543. [CrossRef]

25. Gotsi, M.; Wilson, A.M. Corporate Reputation: Seeking a Definition. Corp. Commun. Int. J. 2001, 6, 24-30. [CrossRef]

26. Brammer, S.; Millington, A. Corporate Reputation and Philanthropy: An Empirical Analysis. J. Bus. Ethics. 2005, 61, 29-44. [CrossRef]

27. Jin, B.; Park, J.Y.; Kim, J. Cross-cultural Examination of the Relationships among Firm Reputation, e-Satisfaction, e-Trust, and e-Loyalty. Int. Mark. Rev. 2008, 25, 324-337. [CrossRef]

28. Stanaland, A.; Lwin, M.; Murphy, P. Consumer perceptions of the antecedents and consequences of corporate social responsibility. J. Bus. Ethics 2011, 102, 47-55. [CrossRef]

29. Su, L.; Huang, S.; van der Veen, R.; Chen, X. Corporate social responsibility, corporate reputation, customer emotions and behavioral intentions: A structural equation modeling analysis. J. China Tour. Res. 2014, 10, 511-529. [CrossRef]

30. Liljander, V.; Strandvik, T. Emotions in Service Satisfaction. Int. J. Serv. Ind. Manag. 1997, 8, $148-169$. [CrossRef]

31. Fredrickson, B.L. The Role of Positive Emotions in Positive Psychology: The Broaden-and-Build Theory of Positive Emotions. Am. Psychol. 2001, 56, 218-226. [CrossRef]

32. Wu, H.C.; Li, T. An Empirical Study of the Effects of Service Quality, Visitor Satisfaction, and Emotions on Behavioral Intentions of Visitors to the Museums of Macau. J. Qual. Assur. Hosp. Tour. 2015, 16, 80-102. [CrossRef]

33. Fombrun, C.; Shanley, M. What's in a name? Reputation building and corporate strategy. Acad. Manag. J. 1990, 33, 233-258.

34. Anderson, E. Customer Satisfaction and Word of Mouth. J. Serv. Res. 1998, 1, 5-17. [CrossRef]

35. Brown, J.J.; Reingen, P.H. Social Ties and Word-of-Mouth Referral Behavior. J. Consum. Res. 1987, 14, 350-362. [CrossRef]

36. Zeelenberg, M.; Pieters, R. Beyond Valence in Customer Dissatisfaction: A Review and New Findings on Behavioral Responses to Regret and Disappointment in Failed Services. J. Bus. Res. 2004, 57, 445-455. [CrossRef]

37. Chin, W.W. The Partial Least Squares Approach to Structural Equation Modeling. Mod. Methods Bus. Res. 1998, 295, 295-336.

38. Im, S.; Bhat, S.; Lee, Y. Consumer Perceptions of Product Creativity, Coolness, Value and Attitude. J. Bus. Res. 2015, 68, 166-172. [CrossRef]

39. Maignan, I. Consumers Perceptions of Corporate Social Responsibilities: A Cross-Cultural Comparison. J. Bus. Ethics. 2001, 30, 57-72. [CrossRef]

40. Kang, B. Corporate Social Responsibility Perceptions and Corporate Performances. J. Appl. Sci. 2014, 14, 2662-2674. [CrossRef]

41. Churchill, G.A., Jr. A Paradigm for Developing Better Measures of Marketing Constructs. J. Mark. Res. 1979, 16, 64-73. [CrossRef] 
42. Gerbing, D.W.; Hamilton, J.G.; Freeman, E.B. A large-scale second-order structural equation model of the influence of management participation on organizational planning benefits. J. Manag. 1994, 20, 859-885. [CrossRef]

43. Gefen, D.; Straub, D. A Practical Guide to Factorial Validity Using PLS-Graph: Tutorial and Annotated Example. Commun. Assoc. Inf. Syst. 2005, 16, 90-110. [CrossRef]

44. Jang, S.S.; Namkung, Y. Perceived Quality, Emotions, and Behavioral Intentions: Application of an Extended Mehrabian-Russell Model to Restaurants. J. Bus. Res. 2009, 62, 451-460. [CrossRef]

(C) 2019 by the authors. Licensee MDPI, Basel, Switzerland. This article is an open access article distributed under the terms and conditions of the Creative Commons Attribution (CC BY) license (http://creativecommons.org/licenses/by/4.0/). 